\title{
THE APPLICATION OF ROLE PLAYS AS AN EFFORT TO IMPROVE THE SPEAKING ABILITY OF THE FIRST YEAR STUDENTS OF SMPN 1 TANAH PUTIH
}

\author{
Mima Putri ${ }^{1}$ and Effendi Gultom ${ }^{*}$ \\ 1Teachers' Training and Education Faculty, Riau University Graduate \\ ${ }^{2}$ English Lecturer, Teachers' Training and Education, Riau University \\ E-mail : effendygultom@gmail.com
}

\begin{abstract}
This is an action research. In doing this research is needed some of the data is used to support the success. The data for this research will be collected by giving pre-test, post-test and observation. In order to get or to collect the data for this study, the writer has to find the suitable instrument. The instrument used for the speaking test as description. The students are asked to speak based on the dialogue given by the teacher. In this speaking, the teacher will observe the students ability in grammar, pronunciation, vocabulary and fluency. In this research the writer involved in every cycle and in collecting the data. The researcher used the Observation sheet and test. The observation sheet is to know the students' speaking ability, a check list is used. The check list is done during the classroom activities. in doing the check list, the researcher will invite collaborators to the classroom. The class however, will be handled by the researcher who is in charge of teaching speaking by using role play. The test was given to the student is in oral form. Before the test is given, the researcher gave a pre-test at the beginning of the cycle and post-test at the end of the cycle. So, in this research, the students are asked to role play their conversation in front of the class based on the conversation given. The students' speaking ability between pretest and post-test in every cycle is increase. The research question was answered and the hypothesis is reliable. The use of role play is an affective technique to improve the students' speaking ability of the first year students of SMP Negeri 1 Tanah Putih in academic year 2010/2011. In conclusion, the speaking ability of the first year students of SMP Negeri 1 Tanah Putih before treatment is poor. But after getting treatment, the students' speaking ability becomes good. It means that the speaking ability of the students is increase.
\end{abstract}

Keywords: , Role Play, Improve, and Speaking Ability

\section{INTRODUCTON}

Based on the level of Education Unit Curriculum 2006 for junior high school as used by SMPN 1 Tanah Putih, English lesson in junior high school is very important. As everybody knows, English as a foreign language has become a compulsory subject for the students. In Indonesia, the government has a decided that English is one of final examination subjects for junior high school students. It is a good decision because the human resources need to access information on science and technology that are presented in English, either in written or spoken forms. The function of English is to provide the students with the four language 
skills: listening, speaking, reading and writing. Speaking ability is basic requirements for junior high school students.

Speaking supposed to be practiced daily in teaching and learning processes in the classroom, but many students still communicate in Indonesian language. Some problems faced by students, those are English is a foreign language English pronunciation is not some with the written like in Indonesian language, the grammatical errors and less expressions. The students are also afraid to speak English because they lack of vocabularies.Based on those problems, the writer will use role play in teaching. The writer thinks that Role Play can improve the students' speaking ability.

Teaching English for beginners with appropriate method can motivate them. Brown and Yule (1994:217) say that there are four language skills that must be learned by the students in English learning. As mentioned, speaking is one of four language skills that need to be learned by the students because in speaking, people will be able to say what they want to express.

The goal of teaching speaking is communicative efficiency. Learners should be able to make themselves understood, using their current proficiency. They should try to avoid confusion in the message due to faulty pronunciation, grammar or vocabulary and to observe the social and cultural rules that applied in each communication situation.

To help students develop communicative efficiency in speaking, instructors can use a balanced approach that combines language input, structured output, and communicative output. Because of the problems above, Ur (1981) says that the use of role play has added a tremendous number of possibilities for communication practice. It was suggested is one of the extracts quoted in the previous unit that one way to vary the kinds of spoken interaction.Based on the theories above, the writer is interested in conducting a research about "The Application of Role Plays as an Effort to Improve the Speaking Ability of the First Year Students of SMPN 1 Tanah Putih”.

\section{METHODOLOGY}

This is an action research. The action research consists of four steps in a cycle. They are planning, action, observing and reflecting. If the problem can not be solved in the first cycle, the research is continued to the next cycle with some revisions in the activities.Below is the description of each cycle of the classroom action research that was conducted by the researcher: 


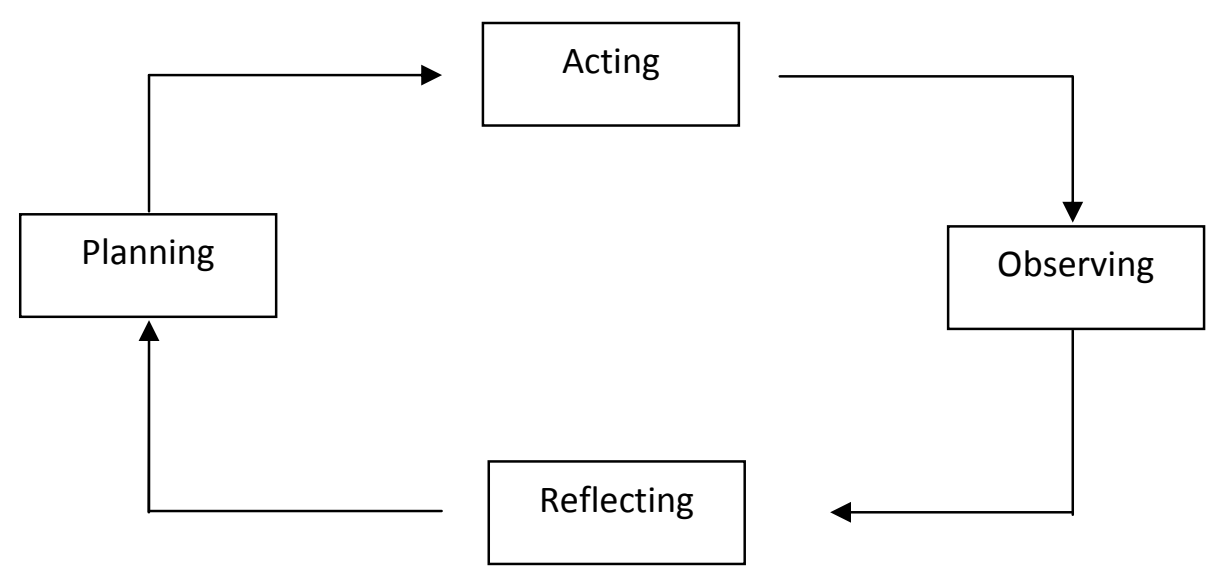

Figure 1. Action ResearchCycle (Kemmis , 1992)

In doing this research is needed some of the data is used to support the success. The data for this research will be collected by giving pre-test, post-test and observation. In order to get or to collect the data for this study, the writer has to find the suitable instrument. The instrument used for the speaking test as description. The students are asked to speak based on the dialogue given by the teacher. In this speaking, the teacher will observe the students ability in grammar, pronunciation, vocabulary and fluency.

In this research the writer involved in every cycle and in collecting the data. The researcher used the instrument as seen below:

1. Observation sheet

Is to know the students' speaking ability, a check list is used. The check list is done during the classroom activities. in doing the check list, the researcher will invite collaborators to the classroom. The class however, will be handled by the researcher who is in charge of teaching speaking by using role play.

2. Test

This research used a test. The test was given to the student is in oral form. Before the test is given, the researcher gave a pre-test at the beginning of the cycle and post-test at the end of the cycle. So, in this research, the students are asked to role play their conversation in front of the class based on the conversation given.

To analyzed the students speaking ability, the following formula is used:

$\mathrm{SA}=\frac{\mathrm{P}+\mathrm{G}+\mathrm{V}+\mathrm{F}}{4}$

SA = Students' Speaking Ability

$\mathrm{P}=$ Students' ability in pronounciation

$\mathrm{G}=$ Students' ability in Grammar 
$\mathrm{V}=$ Students' ability in Vocabulary

$\mathrm{F}=$ Students' ability in Fluency

Table 1. Level of Speaking Ability(Harris : 1974)

\begin{tabular}{|c|c|c|c|c|c|}
\hline Proficiency & Level 5 & Level 4 & Level 3 & Level 2 & Level 1 \\
\hline Pronounciation & 5 & 4 & 3 & 2 & 1 \\
Grammar & 5 & 4 & 3 & 2 & 1 \\
Vocabulary & 5 & 4 & 3 & 2 & 1 \\
Fluency & 5 & 4 & 3 & 2 & 1 \\
\hline
\end{tabular}

So, based on the description above, the classifications of the students' speaking ability can be presented as follows:

Table 2. The level of students' scores(Harris, 1974)

\begin{tabular}{|l|l|l|}
\hline No & \multicolumn{1}{|c|}{ Test score } & \multicolumn{1}{c|}{ Level of ability } \\
\hline 1 & $81-100$ & Very Good \\
\hline 2 & $61-80$ & Good \\
\hline 3 & $41-60$ & Mediocre \\
\hline 4 & $21-40$ & Poor \\
\hline 5 & $0-20$ & Very Poor \\
\hline
\end{tabular}

The pre-test was carried out to determine the background ability of the students. Thespeaking test contains conversations.After the teaching learning process had run for a month, the post-test was conducted in order to know the development of the students who joined the role play techniques in an effort to improve the speaking ability. The administration was at the end of the first cycle.The items used for this speaking test was taken from the items of the previous pre-test. The result of the post-test was analyzed and used as the final data for this research.

\section{RESEARCH FINDINGS}

The students' speaking ability was increase after they were taught by using role play. The increase occurred to most of the students. The improvement occurred because the role play did in every meeting with some of reflection. The improvement of the students' speaking ability also occurred in some proficient list (pronunciation, grammar, vocabulary, fluency and expression).

The result of research is 75.69-38.05 $=37.64$. it shows that the result of the students' speaking ability is increase. So the writer can conclude that the students' speaking ability is satisfactory. The data can be seen in the following table : 
Table 3. The Average Score for Each Components of Speaking in the Post-test

\begin{tabular}{|c|l|l|l|}
\hline No & Component & Average & Level \\
\hline 1. & Pronunciation & 76.07 & Good \\
\hline 2. & Grammar & 74.62 & Good \\
\hline 3. & Vocabulary & 80.90 & Excellent \\
\hline 4. & Fluency & 71.17 & Good \\
\hline
\end{tabular}

And the following table shows the increase of students' scores:

Table 4. The Improvement of Students' Speaking Ability by Using Role Play

\begin{tabular}{|l|l|l|l|l|}
\hline No & \multicolumn{1}{|c|}{ Component } & \multicolumn{1}{|c|}{ Pre-test } & \multicolumn{1}{|c|}{ Post-test } & Improvement \\
\hline 1. & Pronunciation & 39.24 & 76.07 & 36.83 \\
\hline 2. & Grammar & 36.93 & 74.62 & 37.69 \\
\hline 3. & Vocabulary & 40.14 & 80.90 & 40.76 \\
\hline 4. & Fluency & 35.90 & 71.17 & 35.27 \\
\hline
\end{tabular}

From the table above, we can see the increase of students' speaking ability between pre-test and post-test in every cycle. The research question was answered and the hypothesis is reliable. The use of role play is an affective technique to improve the students' speaking ability of the first year students of SMP Negeri 1 Tanah Putih in academic year 2010/2011.

In conclusion, the speaking ability of the first year students of SMP Negeri 1 Tanah Putih before treatment is poor. But after getting treatment, the students' speaking ability becomes good. It means that the speaking ability of the students is increase.

\section{CONCLUSIONS}

After analyzing the data of the students in practicing role plays, the writer can draw the result of the research as follows:

1. There is an increasing of the students' speaking ability of the first year students of SMP Negeri 1 Tanah Putih by using role play.

2. After getting treatment, the students' speaking ability becomes good (75.69), which before treatment is poor (37.64).

3. The increasing score after treatment is $38.05(75.69-37.64)$.

4. So, it means that role plays are affective to improve the students' speaking ability. 


\section{SUGGESTIONS}

Based on the conclusion, the writer would like to propose some suggestions which would be useful for the teachers, the students, and other researchers.

1. After knowing the ability of the first year students of SMP Negeri 1 Tanah Putih - RokanHilir in using role play, it can motivate the students in learning English especially speaking and it can be used to improve the students speaking ability.

2. The teacher needs to apply the suitable methods in teaching English. So, the students can enjoy their learning processes.

3. The students need to focus on teachers' explanations when teaching and learning process.

4. For other language researchers, this thesis may encourage them to conduct other studies concerning role play.

\section{REFERENCES}

Aziz Joeslina, 2004. Strategimengajar, Jakarta

Brown Gillian and Yule George, 1987, Teaching the spoken language : Approach Based on the Analysis of conversational English. Australia, Cambridge University Press.

Chastain, 1975.Developing Second Language skill, Theory to Practice, Second Edition.

Harris, David P. 1974. Testing English as a second Language. McGraw Hill.Inc New York.

Harmer, J. 1984.The Practice of English Language Teaching.London : Longman. Kemmis and Mc. Tanggart, R. 1992. The Action Research Planner. Australia. Third Edition, Oxford University Press, Oxford.

Kims H. John, 2007. Kims Role Playing Games Page - Encyclopedia of Role Playing Games and Companies.

Kalayo and M. FauzanAnsyari. 2007. Teaching English as a foreign Language (TEFL).Riau : UIN SUSKA Riau.

Nunan, David. 1991. Language Teaching methodology. Sydney Macquarie University. Sydney.

Ur, Penny. 1997. A Course in Language Teaching Practice and Theory. Cambridge University Press. 